\title{
In vitro anti-Herpes simplex virus activity of crude extract of the roots of Nauclea latifolia Smith (Rubiaceae)
}

Manuela Donalisio ${ }^{1}$, Huguette Magnifouet Nana ${ }^{1,2}$, Rosalie Annie Ngono Ngane ${ }^{3}$, Donatien Gatsing ${ }^{2}$, Alembert Tiabou Tchinda ${ }^{4}$, Roberta Rovito ${ }^{1}$, Valeria Cagno', Cecilia Cagliero ${ }^{5}$, Fabrice Fekam Boyom ${ }^{6}$, Patrizia Rubiolo ${ }^{5}$, Carlo Bicchi ${ }^{5}$ and David Lembo ${ }^{1,7^{*}}$

\begin{abstract}
Background: Nauclea latifolia Smith, a shrub belonging to the family Rubiaceae is a very popular medicinal plant in Cameroon and neighboring countries where it is used to treat jaundice, yellow fever, rheumatism, abdominal pains, hepatitis, diarrhea, dysentery, hypertension, as well as diabetes. The ethno-medicinal use against yellow fever, jaundice and diarrhea prompted us to investigate on the antiviral activity of the root bark of N. latifolia. In this study, HSV-2 was chosen as a viral model because of its strong impact on HIV transmission and acquisition.

Methods: The crude extract under study was prepared by maceration of air-dried and powdered roots barks of N. latifolia in $\mathrm{CH}_{2} \mathrm{Cl}_{2} / \mathrm{MeOH}$ (50:50) mixture for 48 hours, then it was subjected to filtration and evaporation under vacuum. A phytochemical analysis of the crude extract was performed by High Performance Liquid Chromatography coupled with a photodiode array and mass spectrometry (HPLC-PDA-ESI-qMS). The anti-HSV-2 activity was assayed in vitro by plaque reduction and virus yield assays and the major mechanism of action was investigated by virucidal and time of addition assays. Data values were compared using the Extra sum of squares $F$ test of program GraphPad PRISM 4.
\end{abstract}

Results: The main components detected in the extract belong to the class of indole alkaloids characteristic of Nauclea genus. Strictosamide, vincosamide and pumiloside were tentatively identified together with quinovic acid glycoside. N. latifolia crude extract inhibited both acyclovir sensitive and acyclovir resistant HSV-2 strains, with IC 50 values of $5.38 \mu \mathrm{g} / \mathrm{ml}$ for the former and $7.17 \mu \mathrm{g} / \mathrm{ml}$ for the latter. The extract was found to be most active when added post-infection, with $\mathrm{IC}_{50}$ of $3.63 \mu \mathrm{g} / \mathrm{ml}$.

Conclusion: The results of this work partly justify the empirical use of N. latifolia in traditional medicine for the treatment of viral diseases. This extract could be a promising rough material for the development of a new and more effective modern anti-HSV-2 medication also active against acyclovir-resistant HSV-2 strains.

Keywords: N. latifolia roots, $\mathrm{CH}_{2} \mathrm{Cl}_{2} / \mathrm{MeOH}$ extract, Phytochemistry, Antiviral activity, HSV-2

\footnotetext{
* Correspondence: david.lembo@unito.it

${ }^{1}$ Laboratory of Molecular Virology, Department of Clinical and Biological

Sciences, University of Turin, PO Box 10043, Torino, Italy

${ }^{7}$ Department of Clinical and Biological Sciences, University of Turin, S. Luigi

Gonzaga Hospital, Regione Gonzole, 10, 10043 Orbassano, Turin, Italy

Full list of author information is available at the end of the article
} 


\section{Background}

Genital herpes is a widespread sexually transmitted infection, caused by the herpes simplex virus (HSV), most commonly of type 2 (HSV-2) [1]. After the primary infection, HSV-2 is transported retrogradely to the lumbosacral sensory ganglia, where it establishes a lifelong latent infection that can be reactivated by stress, hormonal changes and UV light. After reactivation, HSV-2 can be transported to the primary site of infection causing either asymptomatic episodes, which facilitate its spread in the population, or recurrent ulcerations to the genital mucosa. These lesions are often very painful and can lead to substantial psychological morbidity [2]. The virus can also be passed from mother to child during birth with the risk of very serious neonatal infections [3]. It has been estimated that the global prevalence in people aged 15-49 years who were living with HSV-2 worldwide in 2003 was 536 million whereas the estimated number of new HSV-2 infections among 15-49 year olds worldwide in 2003 was 23.6 million [4]. The incidence of HSV recurrence is increased in people with an impaired immune system, such as HIV-seropositive individuals and in transplant recipients [5,6]. On the other hand, genital herpes may increase the risk of HIV acquisition by disrupting epithelial cells, with induction of local inflammation and production of cytokines and chemokines that activate and recruit CD4 $4^{+}$HIV target cells [7]. In a systematic review including a meta-analysis of longitudinal studies, prevalent HSV-2 infection was associated with a three-fold increased risk of HIV acquisition in both men and women, suggesting that, in areas of high HSV-2 prevalence, a high proportion of HIV infection is attributable to HSV-2 [8]. Therefore, strategies that can prevent or treat HSV infections are expected to reduce rates of sexual HIV transmission [9]. Currently no vaccine is available. The standard therapy for management of HSV infections is based on nucleoside analogues that target the viral DNA polymerase. These include acyclovir, penciclovir and their derivates, valacyclovir, and famciclovir $[10,11]$. These antiviral drugs can be efficacious to treat clinical signs and symptoms of first and recurrent episodes, but their widespread use and the long term prophylactic therapy may be associated with relative high toxicity and emergence of drug-resistant virus strains especially in immunocompromised patients [12]. For these reasons, there is a great demand for the development of new antiviral drugs with novel mode of action. In this context, natural products from medicinal plant extracts are very important source of anti-HSV agents and several extracts and pure compounds from herbal medicines have been reported to exert an antiHSV activity [13].

African plants constitute a rich and still underexplored source of natural products of potential medical interest
[14]. Nauclea latifolia Smith (syn: Sarcocephalus latifolius (Sm.) Gruce) is a straggling shrub or small tree of about $4 \mathrm{~m}$ high abundantly spread in all inter-tropical Africa. In Cameroon, the roots are used to treat jaundice, yellow fever, rheumatism, abdominal pains and hepatitis and the bark to treat jaundice and loss of appetite [15]. In Nigeria, the stem bark and roots of the plant are used against fever, jaundice, malaria, diarrhea, dysentery, hypertension and diabetes [16]. Pharmacological studies of N. latifolia have shown antibacterial [16], antidiabetic [17] and antiplasmodial [18] activities. Previous phytochemical studies on $N$. latifolia have yielded a great number of indole alkaloids, triterpenes, steroids and saponins [19-21]. The traditional use against yellow fever, jaundice and diarrhea prompted us to investigate on the antiviral activity of the root bark of $N$. latifolia. The present study was undertaken to test the crude extract of $N$. latifolia for its antiviral activity against acyclovir-sensitive and resistant strains of HSV-2 and to investigate its probable mode of action.

\section{Methods}

\section{Plant material}

The root barks of $N$. latifolia were collected in January 2011 at Makenéné (Centre region, Cameroon) and identified at the National herbarium of Yaoundé (Cameroon) where a voucher specimen (No 58281/HNC) was deposited.

\section{Preparation of the crude extract}

The air dried and powdered root barks $(1 \mathrm{Kg})$ of $N$. latifolia were macerated with $\mathrm{CH}_{2} \mathrm{Cl}_{2}-\mathrm{MeOH}$ mixture (6 L) for 48 hrs. Filtration and removal of solvent under vacuum using an evaporator gave a brown extract (30 g) which was subsequently subjected to phytochemical and biological assays.

\section{HPLC-PDA-MS analysis}

$N$. latifolia crude extract was analyzed by a Shimadzu LC-MS 2010EV system equipped with a photodiode detector SPD-M20A (Shimadzu, Dusseldorf Germany) in series to a single quadrupole MS system provided with orthogonal atmospheric pressure chemical ionization (APCI) and electrospray ionization (ESI) sources. An Ascentis Phenyl column $(250 \times 4.6 \mathrm{~mm}$ i.d., $5.0 \mu \mathrm{m})$, (Supelco, Bellefonte, PA) was used. Analysis conditions were: temperature: $40^{\circ} \mathrm{C}$; mobile phase: eluent A: water; eluent B: acetonitrile; mobile phase gradient was as follows: $20-50 \%$ B in $37.5 \mathrm{~min}, 50-90 \%$ B in $16.67 \mathrm{~min}$, and $90 \% \mathrm{~B}$ for $3 \mathrm{~min}$. Injection volume: $10 \mu \mathrm{l}$, flow rate: $0.4 \mathrm{ml} / \mathrm{min}$. UV spectra were acquired in the $210-450 \mathrm{~nm}$ wavelength range and the resulting chromatograms were integrated at different wavelengths in function of the UV absorption maxima of each component. MS operative conditions: ESI temperature: $200^{\circ} \mathrm{C}$; nebulizer gas flow 
rate: $1.5 \mathrm{ml} / \mathrm{min}$; curve desolvation line (CDL) temperature: $250^{\circ} \mathrm{C}$. Mass spectra were acquired both in positive and in negative full-scan mode in the range of 150$900 \mathrm{~m} / \mathrm{z}$, with a scan range of $1000 \mathrm{u} / \mathrm{s}$.

Identification of the components was based on their UV spectra, and mass spectral information compared to those reported in literature with which are in full agreement.

\section{Cell lines and viruses}

African green monkey kidney cells (Vero) (ATCC CCL-81) were cultured in Eagle's minimal essential medium (MEM) (Gibco/BRL, Gaithersburg, MD) supplemented with heatinactivated $10 \%$ foetal calf serum (FCS) (Gibco/BRL) and $1 \%$ antibiotic-antimycotic solution (Zell Shield, Minerva Biolabs $\mathrm{GmbH}$, Berlin, Germany), at $37^{\circ} \mathrm{C}$ in an atmosphere of $5 \%$ of $\mathrm{CO}_{2}$.

A clinical isolate of HSV-2, sensitive to acyclovir was kindly provided by Prof. M. Pistello, University of Pisa, Italy. A HSV-2 strain with phenotypic resistance to acyclovir was generated by serial passage in the presence of increasing concentrations of acyclovir as previously described by Field [22]. The resistant virus was then plaquepurified, and the antiviral susceptibility was tested by a plaque reduction assay showing an inhibitory concentration producing $50 \%$ reduction in plaque formation $\left(\mathrm{IC}_{50}\right)$ of $319 \mu \mathrm{M}$. Viral strains were propagated and titrated by plaque assay on Vero cells, as previously described [23].

\section{Reagents}

Heparin $(13.6 \mathrm{kDa})$ was obtained from Laboratori Derivati Organici Spa (Milan, Italy). Acyclovir (Sigma-Aldrich).

\section{Cell viability assay}

Vero cells were seeded into 96-well plates at a density of $10^{4}$ cells/well, and incubated at $37^{\circ} \mathrm{C}$ in a $5 \% \mathrm{CO}_{2}$ atmosphere for $24 \mathrm{~h}$. Increasing concentrations of the test extract were added to the cells, with a replicate number of three wells per concentration. After a two day incubation period, cell viability was measured by the MTS [3-(4,5-dimethylthiazol-2-yl)-5-(3-carboxymethoxyphenyl)2-(4-sulfophenyl)-2H-tetrazolium] assay by the CellTiter 96 Proliferation Assay Kit (Promega, Madison, WI,USA) according to the manufacturer's instructions. Absorbances were measured using a Microplate Reader (Model 680, BIORAD) at $490 \mathrm{~nm}$. The resulting cell viability was calculated as described previously [24]. The $50 \%$ cytotoxic concentrations $\left(\mathrm{CC}_{50}\right)$ and $95 \%$ confidence intervals $(\mathrm{CI})$ were determined using GraphPad PRISM software (Graph-Pad Software, San Diego, CA).

\section{HSV antiviral assays}

Inhibition of HSV replication was evaluated with plaque reduction assay and virus yield reduction assay. Vero cells were seeded in 24-well plates at a density of $10 \times$
$10^{4}$ cells. The plaque reduction assay was performed infecting cell monolayers with HSV-2 or HSV-2 mutant with phenotypic resistance to acyclovir at a multiplicity of infection (MOI) of $0.001 \mathrm{pfu} / \mathrm{cell}$ in presence of serial dilutions of the test extract for 2 hours at $37^{\circ} \mathrm{C}$. The inocula were subsequently removed from the wells, and the cells were washed with medium twice and overlaid with a medium containing $1.2 \%$ methylcellulose (Sigma) and the plant extract. Treatment of control samples with equal volumes of DMSO was performed in order to rule out the possibility of any cytotoxic effect ascribable to the solvent. After incubation for 24 hours at $37^{\circ} \mathrm{C}$ in $5 \%$ $\mathrm{CO}_{2}$, the supernatant was removed, and the cells were fixed and stained with $0.1 \%$ crystal violet in $20 \%$ ethanol and viral plaques were counted. The $\mathrm{IC}_{50}$ values, defined as the inhibitory concentration producing $50 \%$ reduction in plaque formation, were calculated by using the program GraphPad PRISM 4 (GraphPad Software, San Diego, California, U.S.A.) to fit a variable slope-sigmoidal doseresponse curve. A selectivity index (SI) was calculated by dividing the $\mathrm{CC}_{50}$ by the $\mathrm{IC}_{50}$ values. For the virus yield reduction assay, cells were infected in duplicate with HSV-2 at a MOI of $0.01 \mathrm{pfu} / \mathrm{cell}$ in presence of serial dilutions of extract. Following virus adsorption $\left(2\right.$ hours at $\left.37^{\circ} \mathrm{C}\right)$, the virus inoculum was removed and cultures were exposed to the extract and incubated until control cultures displayed extensive cytopathology. Supernatants were pooled as appropriate 48 hours after infection and cell-free virus infectivity titers were determined in duplicate by the plaque assay in Vero cell monolayers. The end-points of the assay were the inhibitory concentration of extract which reduced virus yield by $50 \%\left(\mathrm{IC}_{50}\right)$ in comparison to the untreated virus control.

\section{Virucidal assay}

The direct effect of $N$. latifolia extract on infection of HSV-2 was evaluated by incubating $33 \mu \mathrm{g} / \mathrm{ml}$ of extract with HSV-2 $\left(10^{5} \mathrm{pfu}\right)$ at either 4 or $37^{\circ} \mathrm{C}$ for various lengths of time as previously described [25,26]. After incubation, the residual virus infectivity was determined by titration on Vero cells at high dilutions, at which the extract was not active.

\section{Pre-treatment assay}

The pre-treatment was performed treating Vero cells in 24-well plate with different concentrations of extract for two hours at $37^{\circ} \mathrm{C}$ prior virus infection. After washing, cells were infected with HSV-2 at a MOI of $0.001 \mathrm{pfu} /$ cell for two hours. The infected cells were washed and treated as described above for plaque reduction assay.

\section{Attachment assay}

The attachment assay was performed as previously described $[25,26]$ by mixing $N$. latifolia extract or heparin 
with HSV-2 (MOI of $0.004 \mathrm{pfu} / \mathrm{cell})$ at $4^{\circ} \mathrm{C}$. The mixtures were then added to cooled Vero cells in 96-well plates and incubated for $2 \mathrm{~h}$ at $4^{\circ} \mathrm{C}$ to allow attachment but not entry. After three washes with cold MEM to remove unbound virus, cells were overlaid with medium containing $1.2 \%$ methylcellulose and shifted to $37^{\circ} \mathrm{C}$. After 24 hours of incubation, cells were stained and viral plaques were counted. As control, cells were infected in presence of equal volumes of DMSO setting 100\% of infection; instead, to confirm viral attachment but not viral entry at $4^{\circ} \mathrm{C}$, after incubation cells were treated for two minutes with cold acidic glycine (100 mM glycine, $150 \mathrm{mM} \mathrm{NaCl}, \mathrm{pH}$ 3) to inactivate attached virus, resulting in $100 \%$ inhibition of infection.

\section{Entry assay}

For entry assay, HSV-2 at a MOI of 0.004 pfu/cell was adsorbed for 2 hours at $4^{\circ} \mathrm{C}$ on prechilled confluent Vero cells. Cells were then washed with cold MEM three times to remove unbound virus, treated with different concentrations of extract, and incubated for three hours at $37^{\circ} \mathrm{C}$. Unpenetrated viruses were inactivated with acidic glycine for 2 minutes at room temperature, as previously described [25]. Cells were then washed with warm medium three times and treated as described above for plaque reduction assay.

\section{Post-treatment assay}

For the post-treatment assays Vero cells monolayers were infected with HSV-2 for two hours at $37^{\circ} \mathrm{C}$, followed by two gentle washes to remove unbound viruses. Increasing concentrations of extract were then added to cultures. The IC50 values were measured by plaque reduction assay and virus yield reduction assay, as described previously.

\section{Statistics}

$\mathrm{IC}_{50}$ values were compared using the Extra sum of squares F test of program GraphPad PRISM 4 (GraphPad Software, San Diego, California, U.S.A.). Values of $p<0.05$ were considered indicative of statistical differences. Results represent the mean of three independent experiments \pm standard deviations.

\section{Results}

\section{Phytochemical analysis}

$N$. latifolia belongs to the Rubiaceae family which is characterized by the presence of different classes of secondary metabolites, the most common and investigated of them are alkaloids and saponins because of their biological properties.

Figure 1 reports the HPLC-PDA chromatogram of the crude extract from $N$. latifolia. Table 1 reports the list of the components tentatively identified by HPLC-PDA-ESIqMS in the crude extract, together with their UV absorption maxima and MS data. Mass spectra, acquired in positive and negative ESI ionization (full scan) in general gave protonated $[\mathrm{MH}]^{+}$or deprotonated $[\mathrm{M}-\mathrm{H}]^{-}$molecular ions respectively and, in positive mode, some molecular ion adducts $[\mathrm{M}+\mathrm{Na}]^{+}$and $[\mathrm{M}+\mathrm{K}]^{+}$. The molecular mass of an unknown component was retained only when both $[\mathrm{MH}]^{+}$and $[\mathrm{M}-\mathrm{H}]^{-}$ions were detected. The main components detected in the extracts belong to the class of indole alkaloids characteristic of Nauclea genus. In agreement with the literature data, strictosamide $(3, \mathrm{RT}=$ $21,675 \mathrm{~min}$ ) seems to be the most abundant component in $N$. latifolia crude extract on the basis of its UV absorption maxima and the molecular ions in positive and negative ESI mode [27]. A less abundant component with UV maxima and molecular ions analogue to strictosamide that can be hypothesized as vincosamide $(4, \mathrm{RT}=25,184 \mathrm{~min})$ is

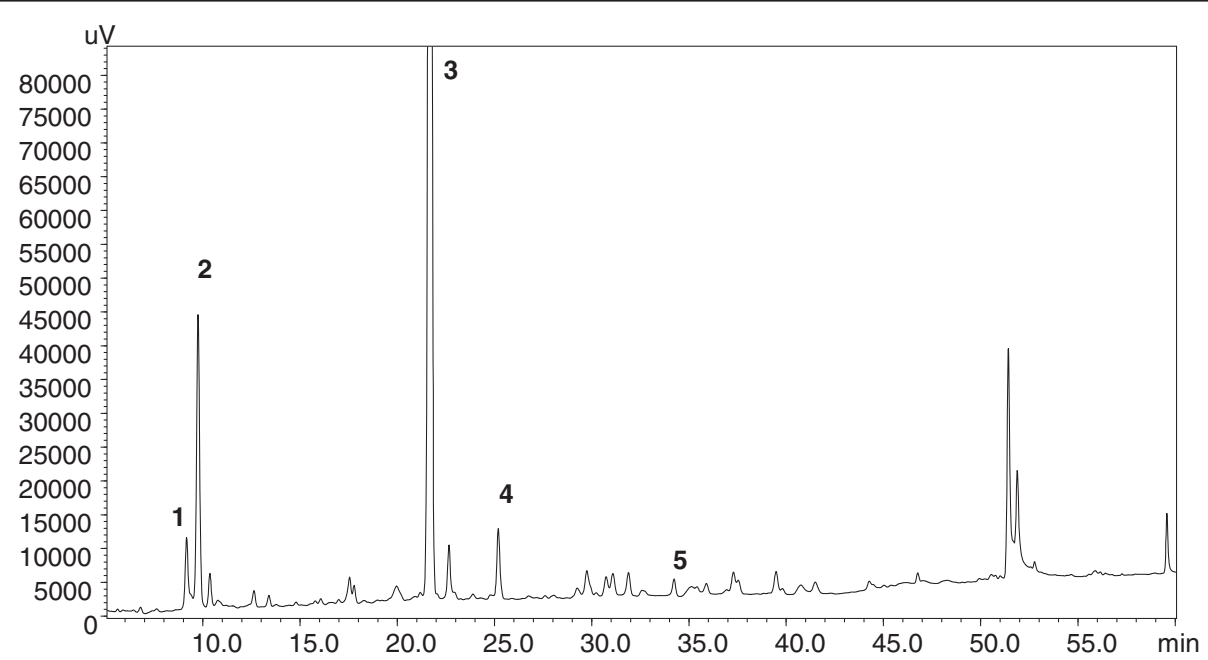

Figure 1 HPLC-PDA analysis of Nauclea latifolia crude extract. Peaks' number are referred to those reported in Table 1. 
Table 1 Nauclea latifolia crude extract composition obtained through HPLC-PDA-ESI-MS analysis

\begin{tabular}{|c|c|c|c|c|c|c|}
\hline ID number & Compound name & (RT min) & UV max & Molecular weight & $\mathrm{ESI}+$ & ESI - \\
\hline \multirow[t]{3}{*}{1} & Pumiloside & 9.16 & 243 & 512 & 513 & 511 \\
\hline & & & 315 & & $535[\mathrm{M}+\mathrm{Na}]^{+}$ & \\
\hline & & & 328 & & $551[\mathrm{M}+\mathrm{K}]^{+}$ & \\
\hline \multirow[t]{3}{*}{2} & Alkaloid? & 9.749 & 221 & 574 & 575 & 573 \\
\hline & & & & & $597[\mathrm{M}+\mathrm{Na}]^{+}$ & \\
\hline & & & & & $613[\mathrm{M}+\mathrm{K}]^{+}$ & \\
\hline \multirow[t]{4}{*}{3} & Strictosamide & 21.675 & 223 & 498 & 499 & 497 \\
\hline & & & & & $521[\mathrm{M}+\mathrm{Na}]^{+}$ & \\
\hline & & & & & $537[\mathrm{M}+\mathrm{K}]^{+}$ & \\
\hline & & & & & $3337[\mathrm{M}+\mathrm{H}-162]^{+}$ & \\
\hline \multirow[t]{3}{*}{4} & Vincosamide & 25.184 & 223 & 498 & 499 & 497 \\
\hline & & & & & $521[\mathrm{M}+\mathrm{Na}]^{+}$ & \\
\hline & & & & & $537[\mathrm{M}+\mathrm{K}]^{+}$ & \\
\hline \multirow[t]{2}{*}{5} & Quinovic acid glycoside? & 34.224 & - & 632 & 633 & 631 \\
\hline & & & & & & $5587[\mathrm{M}-\mathrm{H}-44]$ \\
\hline
\end{tabular}

also present. The presence of pumiloside $(1, \mathrm{RT}=9,16 \mathrm{~min})$ is confirmed by comparison of its UV maxima and molecular ions with those reported in the literature [28]. Compound 5 ( $\mathrm{RT}=34,224 \mathrm{~min}$ ) has tentatively been identified as quinovic acid glycoside (a saponin) on the basis of its spectral data and those reported in literature [29]. Other components probably belonging to the same class (saponins or alkaloids) on the basis of their UV spectra were also detected; their identity is under investigation.

\section{Nauclea latifolia extract inhibits HSV-2 infectivity}

The antiviral activity of a $N$. latifolia extract was examined in vitro by plaque reduction assay against a clinical isolate of HSV-2 sensitive to acyclovir, and a mutant with phenotypic resistance to acyclovir. Vero cells were infected with virus in presence of different extract concentrations, ranging from $100 \mu \mathrm{g} / \mathrm{ml}$ to $0.13 \mu \mathrm{g} / \mathrm{ml}$, and incubated for two hours at $37^{\circ} \mathrm{C}$. The serial dilutions of plant extract were added again after the removal of the virus inoculum. The dose-response curves shown in Figure 2 demonstrate that the extract exerts a remarkable antiviral activity which is independent on the virus sensitivity to acyclovir. The $\mathrm{IC}_{50}$ values for the HSV-2 acyclovir-sensitive or resistant strain are $7.17 \mu \mathrm{g} / \mathrm{ml}$ (95\% CI: 5.36 to 9.59 ) and $5.38 \mu \mathrm{g} / \mathrm{ml}$ (95\% CI: 4.15 to 6.99) respectively. The antiviral activity of the extract was confirmed by a virus yield reduction assay, a more stringent test which allows multiple cycles of viral replication to occur before measuring the production of infectious viruses. Under this condition, the extract reduced the yield of the acyclovir-sensitive HSV-2 with an $\mathrm{IC}_{50}$ value of $1.46 \mu \mathrm{g} / \mathrm{ml}$ (95\% CI: 1.07 to 1.91$)$.
To examine the effect on the cell viability, the extract was serially diluted and added to cell culture medium. For all cell culture experiments $N$. latifolia extract dilutions resulted in a DMSO concentration below 1\% which had no effect on cells and viruses. After 48 hours of incubation at $37^{\circ} \mathrm{C}$, viability of Vero cells was determined by MTS assay. As reported in Figure 3, the extract did not affect Vero cell viability at any concentration tested. The $\mathrm{CC}_{50}$ value was above $100 \mu \mathrm{g} / \mathrm{ml}$, indicating that the antiviral activities observed were not due to cytotoxicity. Moreover, no changes in cell morphology compared with the control were observed by microscopic examination of the cell monolayers (data not shown). According to results of virus yield reduction assay, the selectivity

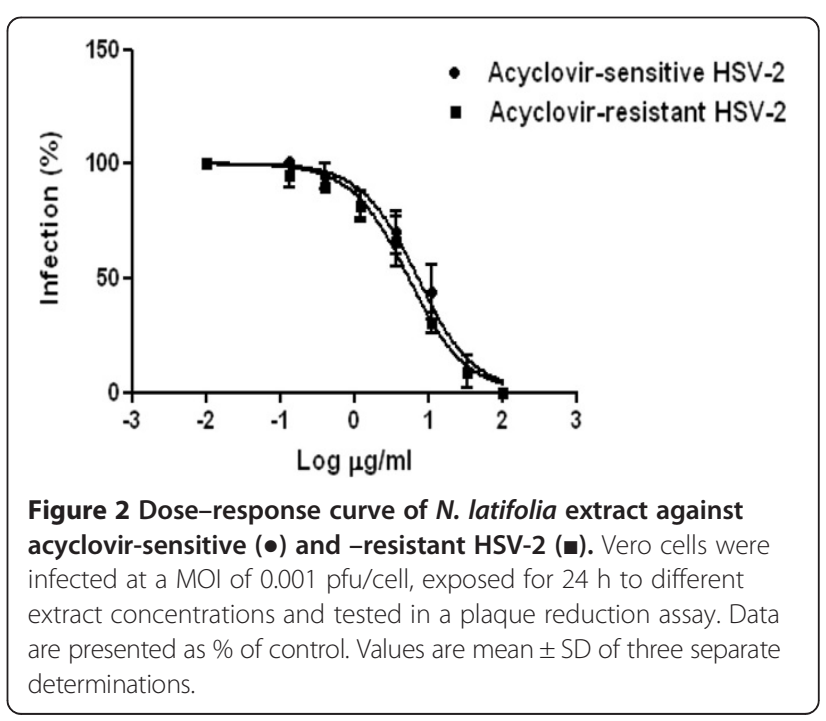




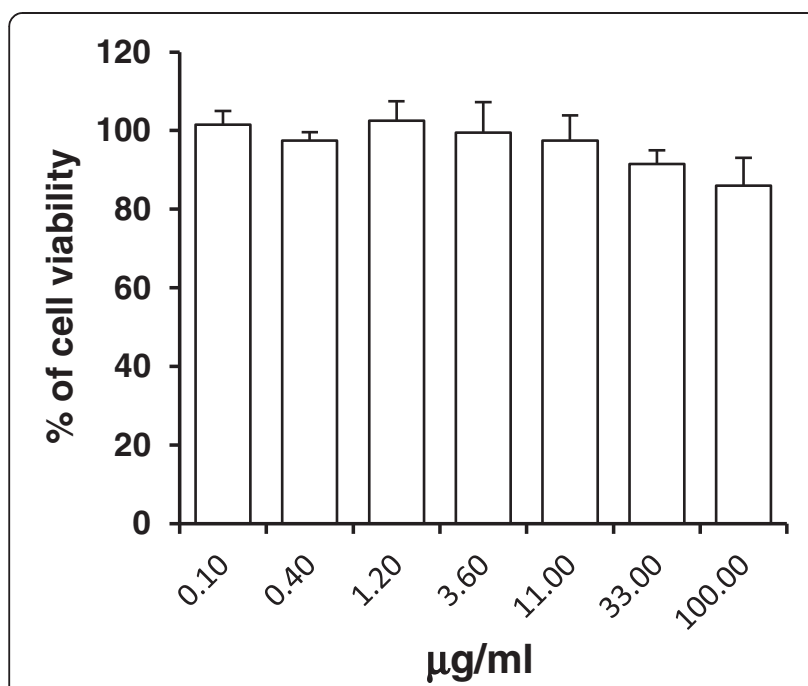

Figure 3 Effect of $N$. latifolia extract on non-infected Vero cells viability, as a function of concentration at $\mathbf{4 8} \mathrm{h}$. $\mathrm{X}$ axis: extract concentration, $Y$ axis: cell viability (\% of control). Each point represent the mean \pm S.D. $(n=3)$

index, a measure of the preferential antiviral activity of a drug in relation to its cytotoxicity, is above 68.4.

\section{Investigation of the major antiviral mechanism of action of extract}

To explore if the extract exerts a direct virus-inactivating activity, a virucidal assay was performed with an extract concentration that reduces almost completely virus infection $\left(\mathrm{IC}_{90}\right)$. To this aim, HSV-2 aliquots were incubated with $33 \mu \mathrm{g} / \mathrm{ml}$ of extract at $4^{\circ} \mathrm{C}$ or $37^{\circ} \mathrm{C}$. After incubation, the samples were titrated on Vero cells at high dilutions at which the extract was not active. As reported in Table 2, this treatment did not produce a significant loss of HSV-2 infectivity, even at a concentration higher than its $\mathrm{IC}_{50}$. Therefore, since the antiviral activity was not exerted

Table 2 Virucidal assay: effect of preincubation of $\boldsymbol{N}$. latifolia extract with HSV-2

\begin{tabular}{|c|c|c|c|}
\hline \multicolumn{2}{|c|}{ Incubation condition } & \multirow[t]{2}{*}{ Extract $^{a}$} & \multirow[t]{2}{*}{${\text { Virus titer }(\mathrm{PFU})^{\mathbf{b}}}^{\mathbf{b}}$} \\
\hline Temp ( $\left.{ }^{\circ} \mathrm{C}\right)$ & Duration (h) & & \\
\hline 37 & 0 & - & $5.56 \times 10^{5}$ \\
\hline 37 & 0 & + & $3.52 \times 10^{5}$ \\
\hline 37 & 2 & - & $5.29 \times 10^{4}$ \\
\hline 37 & 2 & + & $3.42 \times 10^{4}$ \\
\hline 4 & 2 & - & $4.88 \times 10^{5}$ \\
\hline 4 & 2 & + & $6.03 \times 10^{5}$ \\
\hline
\end{tabular}

${ }^{\mathrm{a} C o n c e n t r a t i o n: ~} 33 \mu \mathrm{g} / \mathrm{ml}$.

${ }^{b}$ The values are the means \pm SD of data derived from three independent experiments performed in duplicate. directly on HSV-2 particles before, we explored the effect of the extract on virus-cell interaction performing specific assays.

To identify the stage of the virus replication cycle at which the extract acts, it was added to confluent Vero cells at different time intervals relative to virus infection. In all experiments cells infected with untreated virus were used as control and the inhibition of plaque formation by the extract was evaluated (Figure 4).

The pre-treatment assay shows that various doses of $N$. latifolia extract added 2 hours prior to virus infection and then being washed out did not exert inhibitory activity. Next, mixtures of HSV-2 and different concentrations of extract were added to Vero cells and incubated for two hours at $4^{\circ} \mathrm{C}$ to investigate the possible effect on the virus attachment to cells. A slight dose-response effect of extract on viral attachment was observed with an $\mathrm{IC}_{50}$ of $56.18 \mu \mathrm{g} / \mathrm{ml}$ (95\% CI: 38.0 to 82.89 ). Since this value is more than two $\log$ higher than the $\mathrm{IC}_{50}$ value of heparin $(0.14 \mu \mathrm{g} / \mathrm{ml})$, a known inhibitor of HSV attachment (data not shown) [30], these data suggested that inhibition of attachment is not the main mechanism of action of $N$. latifolia extract. The entry assay was conducted to assess whether the extract prevents the viral penetration into the host cells. As shown in Figure 4 the extract does not act at this stage of the virus replication cycle. In contrast, when the extract was added to the overlay medium after entry of virus into Vero cells, a significant suppression of HSV-2 replication was observed with a $\mathrm{IC}_{50}$ value of of $3.63 \mu \mathrm{g} / \mathrm{ml}(95 \% \mathrm{CI}: 2.6$ to 5.08). The strong inhibitory effect of the tested extract in post-treatment assay was also confirmed by the virus yield reduction assay with an $\mathrm{IC}_{50}$ of $8.23 \mu \mathrm{g} / \mathrm{ml}(95 \%$ CI: 5.33 to 12.70 ) (Figure 4).

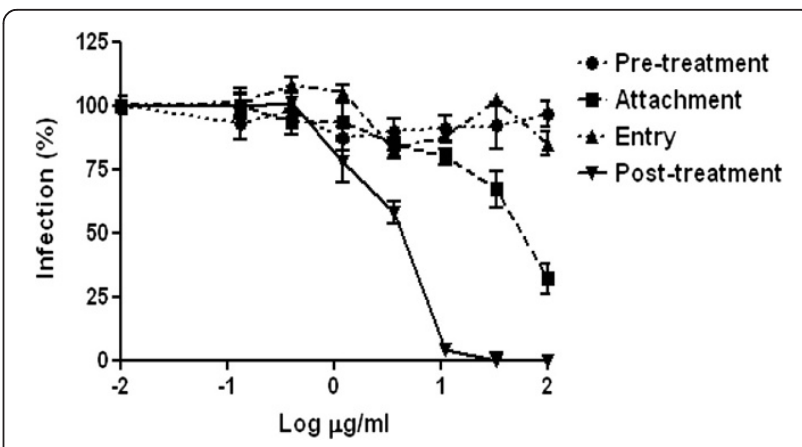

Figure 4 Effect of $N$. latifolia treatment on plaque formation when added to cell cultures at different time intervals relative to virus infection. Cells were pre-treated with extract prior to virus infection (pre-treatment), during the attachment period (attachment), during the entry period (entry) or after infection (post-treatment). Data are presented as $\%$ of control. Values are mean \pm SD of three separate determinations. 


\section{Discussion}

$N$. latifolia belongs to Rubiaceae, a large family comprising more than 630 genera and about 13000 species of plants. Some of them, including $N$. latifolia, are used in sub-Saharan traditional medicine to treat several diseases suggesting that they may represent a natural source of pharmacologically active substances [31]. Although a number of studies indicated a potential therapeutic use of $N$. latifolia [16-18,32-34] at the best of our knowledge its antiviral activity has not been investigated so far. To explore the antiviral potential of $N$. latifolia, HSV-2 was chosen as a viral model because this virus has a strong impact on HIV transmission and acquisition $[9,35,36]$. Indeed, it has been proposed that in areas with a high HIV and HSV-2 prevalence, such as subSaharan Africa, antiviral therapy against HSV-2 could have a population-level impact on the global HIV epidemic $[8,9,37,38]$. Within a study to screen the biological activity of plants native of Central Africa, the present study reports for the first time a remarkable anti-HSV-2 activity of a $\mathrm{CH}_{2} \mathrm{Cl}_{2}-\mathrm{MeOH}$ root barks extract of $N$. latifolia. Although a crude extract may contain several molecules endowed with antiviral activity each acting through a different mechanism some preliminary conclusions can be drawn on the main mode of antiviral action. Further in depth study on the $N$. latifolia extract composition are under way. The virucidal assay rules out the possibility that the antiviral activity of the extract is exerted by a direct inactivation of the virus particle. Time of addition experiments revealed that the strongest inhibition occurs when the extract is added postinfection. These findings indicate that the main mechanism of action is not the inhibition of virus attachment or entry. Moreover, the acyclovir-resistant HSV-2 strain was as susceptible to $N$. latifolia extract as the acyclovirsensitive strain, suggesting that the mode of antiviral action is different from that of acyclovir. This latter feature, along with a low cytotoxicity and a favourable selectivity index make the $N$. latifolia extract a promising starting material for a bioguided-fractionation aimed at identifying anti-HSV-2 compounds with a novel mechanism of action that can be used against acyclovirresistant HSV-2 strains.

\section{Conclusion}

The results of the present study are in line with the use of $N$. latifolia for treatment of viral diseases in African folk medicine. $\mathrm{IC}_{50}$ values allow us to believe that $N$. latifolia roots constitute a natural source of anti-HSV2 substances, although further work remains to be done in order to isolate the active principle and elucidate its mechanism of action, or to develop a phytodrug from $N$. latifolia $\mathrm{CH} 2 \mathrm{Cl} 2 / \mathrm{MeOH}$ extract.

\section{Abbreviations}

HSV: Herpes simplex virus; $\mathrm{CH}_{2} \mathrm{Cl}_{2}$ : Methylene chloride; $\mathrm{MeOH}$ : Methanol; HIV: Humane immune-deficiency virus; $I_{50}$ : Inhibitory concentration producing 50\% reduction in plaque formation; HPLC: High pressure liquid chromatography; PDA: Phtodiode array; MS: Mass spectroscopy; APCl: Atmospheric pressure chemical ionization; ESI: Electrospray ionization; CDL: Desolvation line; MEM: Eagle's minimal essential medium; MTS: 3-(4,5dimethylthiazol-2-yl)-5-(3-carboxymethoxyphenyl)-2-(4-sulfophenyl)-2 $\mathrm{H}$ tetrazolium; MOl: Multiplicity of infection; DMSO: Dimethyl sulfoxide; PFU: Plaque forming unit; SI: Selectivity index; Cl: Confidence interval.

\section{Competing interests}

The authors declare that they have no competing interests.

\section{Authors' contributions}

MD performed the antiviral assays, produced the acyclovir resistant HSV-2 strain, did the statistical analysis of the data and drafted the manuscript. HMN collected ethnobotanical data on the plant as well as the plant itself in the field, prepared the crude extract, participated in antiviral assays and manuscript drafting. RANN, DG and FFB were involved in conception and supervision (ethnobotanical data and plant collection in the field) of this work, and deep manuscript revision. ATT provided laboratory means for preparation of the crude extract and revised the manuscript. RR and VC did the virus time of addition assays. PR, CC and CB performed the phytochemical analyses on N.latifolia crude extract and interpreted the obtained data. DL supervised the work on the whole and provided laboratory means for the antiviral assays. All authors contributed substantially to the present work then read and approved the final manuscript.

\section{Authors' information}

MD is an assistant Professor working in the Laboratory of Molecular Virology, University of Turin, Italy.

$\mathrm{HMN}$ is a PhD student working in Laboratory of Microbiology and Antimicrobial Substances, University of Dschang, Cameroon. She was awarded a funding by AIRES-Sud program for an internship in the Laboratory of Molecular Virology at the University of Turin to learn the techniques of antiviral assays.

RANN is Associate Professor, Head of Department of Biochemistry at the University of Douala, Cameroon; she coordinated the AIRES-Sud funded project number 7082. She is also one of miss Magnifouet's PhD supervisors. DG is Associate Professor, Senior lecturer at the Department of Biochemistry, University Dschang, Cameroon; he is moreover one of miss Magnifouet's PhD supervisors.

ATT is Senoir researcher at the Laboratory of Phytochemistry of the Institute of Medical Research and Medicinal Plants Studies in Yaoundé, Cameroon. VC is PhD student working in the Laboratory of Molecular Virology, University of Turin, Italy.

RR is Master of Science; she carried out her research in the Laboratory of Molecular Virology, University of Turin, Italy.

CC is an assistant Professor working in the laboratory of Phytoanalysis at the Department of Drug Science and Technology, University of Turin.

FFB is Associate Professor, Head of the Laboratory of Phytobiochemistry and medicinal plants study, University of Yaoundé, Cameroon; besides he is one of miss Magnifouet's PhD supervisors.

PR is Professor, Senior lecturer working in the Laboratory of Phytoanalysis at the Department of Drug Science and Technology, University of Turin, Italy.

CB is Professor, Head of the Laboratory of Phytoanalysis, at the Department of Drug Science and Technology,University of Turin, Italy. He is Cagliero's research supervisor.

$\mathrm{DL}$ is Professor, Head of the Laboratory of Molecular Virology, University of Turin, Italy. He is also Donalisio's Cagno's and Rovito' research supervisor.

\section{Acknowledgements}

The authors are grateful to AIRES-Sud, a program of the French Ministry of Foreign and European Affairs implemented by the "Institut de Recherche pour le Développement" (IRD-DSF) who funded miss Magnifouet's stay in Italy. 


\section{Author details}

${ }^{1}$ Laboratory of Molecular Virology, Department of Clinical and Biological Sciences, University of Turin, PO Box 10043, Torino, Italy. ${ }^{2}$ Laboratory of Microbiology and Antimicrobial Substances, University of Dschang, PO Box 67, Dschang, Cameroon. 'Laboratory of Biochemistry, University of Douala, PO Box 24157, Douala, Cameroon. ${ }^{4}$ Laboratory of Phytochemistry, Institute of Medical Research and Medicinal Plants Studies, PO Box 6163, Yaoundé, Cameroon. ${ }^{5}$ Laboratory of Phytoanalysis, Department of Drug Science and Technology, University of Turin, PO Box 10125, Torino, Italy. ' Laboratory of Phytobiochemistry and medicinal plants study, Department of Biochemistry, University of Yaoundé, PO Box 812, Yaoundé, Cameroon. 'Department of Clinical and Biological Sciences, University of Turin, S. Luigi Gonzaga Hospital, Regione Gonzole, 10, 10043 Orbassano, Turin, Italy.

Received: 2 May 2013 Accepted: 24 September 2013 Published: 16 October 2013

\section{References}

1. Whitley RJ, Roizman B: Herpes simplex virus infections. Lancet 2001, 357:1513-1518.

2. Stanberry LR, Cunningham AL, Mindel A, Scott LL, Spruance SL, Aoki FY, Lacey CJ: Prospects for control of herpes simplex virus disease through immunization. Clin Infect Dis 2000, 30:549-566.

3. Brown ZA, Selke S, Zeh J, Kopelman J, Maslow A, Ashley RL, Watts DH, Berry S, Herd M, Corey L: The acquisition of herpes simplex virus during pregnancy. N Engl J Med 1997, 337:509-515.

4. Looker KJ, Garnett GP, Schmid GP: An estimate of the global prevalence and incidence of herpes simplex virus type 2 infection. Bull World Health Organ 2008, 86:805-812.

5. Wald A, Link K: Risk of human immunodeficiency virus infection in herpes simplex virus type 2-seropositive persons: a meta-analysis. J Infect Dis 2002, 185:45-52.

6. Greenberg MS, Friedman H, Cohen SG, Oh SH, Laster L, Starr S: A comparative study of herpes simplex infections in renal transplant and leukemic patients. J Infect Dis 1987, 156:280-287.

7. Carr DJ, Tomanek L: Herpes simplex virus and the chemokines that mediate the inflammation. Curr Top Microbiol Immunol 2006, 303:47-65.

8. Freeman EE, Weiss HA, Glynn JR, Cross PL, Whitworth JA, Hayes RJ: Herpes simplex virus 2 infection increases HIV acquisition in men and women: systematic review and meta-analysis of longitudinal studies. Aids 2006, 20:73-83.

9. Corey $L$, Wald A, Celum CL, Quinn TC: The effects of herpes simplex virus2 on HIV-1 acquisition and transmission: a review of two overlapping epidemics. J Acquir Immune Defic Syndr 2004, 35:435-445.

10. Brady RC, Bernstein DI: Treatment of herpes simplex virus infections. Antiviral Res 2004, 61:73-81.

11. Gupta R, Warren T, Wald A: Genital Herpes. Lancet 2007, 370:2127-2137

12. Bacon TH, Boon RJ, Schultz M, Hodges-Savola C: Surveillance for antiviralagent-resistant herpes simplex virus in the general population with recurrent herpes labialis. Antimicrob Agents Chemother 2002, 46:3042-3044.

13. Khan MT, Ather A, Thompson KD, Gambari R: Extracts and molecules from medicinal plants against herpes simplex viruses. Antiviral Res 2005, 67(2):107-19.

14. Bringmann G, Pokorny F: The Naphthylisoquinoline alkaloids. In The Alkaloids, Volume 46. Edited by Cordell G. New York: Academic University Press; 1995:127-271.

15. Adjanohoun JE, Aboubakar N, Dramane K, Ebot ME, Ekpere JA, Enow-Orock EG, Focho D, Gbilé ZO, Kamanyi A, Kamsu KJ, Keita A, Mbenkum T, Mbi CN Mbiele AL, Mbome IL, Mubiru NK, Nancy WL, Nkongmeneck B, Satabié B, Sofowora A, Tamze V, Wirmum CW: Contribution to Ethnobotanical and Floristic Studies in Cameroon. Addis Ababa: CSTR/OUA; 1996.

16. Okwori AEJ, Okeke Cl, Uzoechina A, Etukudoh NS, Amali MN, Adetunji JA, Olabode AO: The antibacterial potentials of Nauclea latifolia. Afr $J$ Biotechnol 2008, 7:1394-1399.

17. Gidado A, Ameh DA, Atawodi SE: Effect of Nauclea latifolia leaves aqueous extracts on blood glucose levels of normal and alloxan-induced diabetic rats. Afr J Biotech 2005, 4:91-93.

18. Benoit-Vical F, Valentin A, Cournac V, Pélissier Y, Mallié M, Bastide JM: In vitro antiplasmodial activity of stem and root extracts of Nauclea latifolia S.M. (Rubiaceae). J Ethnopharmacol 1998, 61:173-178.
19. Ngnokam D, Ayafor JF, Connolly JD, Nuzillard JM: Nauclefolinine: a new alkaloid from the roots of Nauclea latifolia. Bull Chem Soc Ethiop 2003, 17:173-176.

20. Shigemori H, Kagata T, Ishiyama H, Morah F, Ohsaki A, Kobayashi J: Naucleamides A-E, new monoterpene indole alkaloids from Nauclea latifolia. Chem Pharm Bull 2003, 51:58-61.

21. Abreu P, Pereira A: New indole alkaloids from Sarcocephaleus latifolius. Nat Prod Lett 2001, 15:43-48.

22. Field HJ, Darby G, Wildy P: Isolation and characterization of acyclovirresistant mutants of herpes simplex virus. J Gen Virol 1980, 49(1):115-24.

23. Cavalli $R$, Donalisio M, Bisazza A, Civra A, Ranucci E, Ferruti P, Lembo D: Enhanced antiviral activity of acyclovir loaded into nanoparticles. Methods of Enzymology 2012, 509:1-19.

24. Lembo D, Swaminathan S, Donalisio M, Civra A, Pastero L, Aquilano D, Vavia P, Trotta F, Cavalli R: Encapsulation of Acyclovir in new carboxylated cyclodextrin-based nanosponges improves the agent's antiviral efficacy. Int J Pharm 2013, 443:262-272.

25. Shogan B, Kruse L, Mulamba GB, Hu A, Coen DM: Virucidal activity of a GT-rich oligonucleotide against herpes simplex virus mediated by glycoprotein B. J Virol 2006, 80:4740-4747.

26. Donalisio M, Rusnati M, Cagno V, Civra A, Bugatti A, Giuliani A, Pirri G, Volante M, Papotti M, Landolfo S, Lembo D: Inhibition of human respiratory syncytial virus infectivity by a dendrimeric heparan sulfatebinding peptide. Antimicrob Agents Chemother 2012, 56:5278-5288.

27. Erdelmeier CAJ, Wright AD, Orjala J, Baumgartner B, Rali T, Sticher O: New indole alkaloid glycosides from Nauclea latifolia. Planta Med 1991, 57:149-152.

28. Zhang Z, ElSohly HN, Jacob MR, Pasco DS, Walker LA, Clark AM: New indole alkaloids from the bark of Nauclea orientalis. J Nat Prod 2001, 64:1001-1005.

29. Aquino R, De Tommasi T, De Simone F, Pizza C: Triterpenes and quinovic acid glycosides from Uncaria tomentosa. Phytochemistry 1997, 45:1035-1040.

30. Shieh MT, WuDunn D, Montgomery RI, Esko JD, Spear PG: Cell surface receptors for herpes simplex virus are heparan sulfate proteoglycans. J Cell Biol 1992, 116:1273-1281.

31. Karou SD, Tchacondo T, Ilboudo DP, Simpore J: Sub-Saharan Rubiaceae: a review of their traditional uses, phytochemistry and biological activities. Pak J Biol Sci 2011, 14:149-169.

32. Tekwu EM, Pieme AC, Beng VP: Investigations of antimicrobial activity of some Cameroonian medicinal plant extracts against bacteria and yeast with gastrointestinal relevance. J Ethnopharmacol 2012, 142:265-273.

33. Taïwe GS, Bum EN, Talla E, Dimo T, Weiss N, Sidiki N, Dawe A, Moto FC, Dzeufiet PD, De Ward M: Antipyretic and antinociceptive effects of Nauclea latifolia root decoction and possible mechanisms of action. Pharm Biol 2011, 49:15-25.

34. Abbah J, Amos S, Chindo B, Ngazal I, Vongtau HO, Adzu B, Farida T, Odutola AA, Wambebe C, Gamaniel KS: Pharmacological evidence favouring the use of Nauclea latifolia in malaria ethnopharmacy: effects against nociception, inflammation, and pyrexia in rats and mice. J Ethnopharmacol 2010, 127:85-90

35. Mbopi-Keou FX, Gresenguet G, Mayaud P, Weiss HA, Gopal R, Matta M, Paul $J$, Brown DW, Hayes RJ, Mabey DC, Bélec L: Interactions between herpes simplex virus type 2 and human immunodeficiency virus type 1 infection in African women: opportunities for intervention. J Infect Dis 2000, 182:1090-1096.

36. Serwadda DGray RHSewankambo NKWabwire-Mangen F, Chen MZ, Quinn TC, Lutalo T, Kiwanuka N, Kigozi G, Nalugoda F, Meehan MP, Ashley Morrow R, Wawer MJ: Human immunodeficiency virus acquisition associated with genital ulcer disease and herpes simplex virus type 2 infection: a nested case-control study in Rakai, Uganda. J Infect Dis 2003, 188:1492-1497.

37. Celum CL, Robinson NJ, Cohen MS: Potential effect of HIV type 1 antiretroviral and herpes simplex virus type 2 antiviral therapy on transmission and acquisition of HIV type 1 infection. J Infect Dis 2005, 191:S107-114.

38. White RG, Freeman EE, Orroth KK, Bakker R, Weiss HA, O'Farrell N, Buvé A, Hayes RJ, Glynn JR: Population-level effect of HSV-2 therapy on the incidence of HIV in sub-Saharan Africa. Sex Transm Infect 2008, 84:ii12-8.

doi:10.1186/1472-6882-13-266

Cite this article as: Donalisio et al.: In vitro anti-Herpes simplex virus activity of crude extract of the roots of Nauclea latifolia Smith (Rubiaceae). BMC Complementary and Alternative Medicine 2013 13:266. 